\section{Cureus}

Received 08/20/2018

Review began 09/10/2018

Review ended 09/20/2018

Published 10/02/2018

C) Copyright 2018

Shih et al. This is an open access article distributed under the terms of the Creative Commons Attribution License CC-BY 3.0., which permits unrestricted use, distribution, and reproduction in any medium, provided the original author and source are credited.

\title{
Metatypical Basal Cell Carcinoma with Intravascular Invasion
}

\author{
Shawn Shih ${ }^{1}$, Christina Dai ${ }^{1}$, Ahmed Ansari ${ }^{2}$, Jeffrey Greenwald ${ }^{2}$ \\ 1. Internal Medicine, University of Central Florida College of Medicine, Orlando, USA 2. Dermatology, \\ University of Central Florida College of Medicine, Orlando, USA
}

$\square$ Corresponding author: Shawn Shih, shawnshih12@gmail.com

Disclosures can be found in Additional Information at the end of the article

\section{Abstract}

Basal cell carcinoma is the most common malignancy worldwide, but it very rarely metastasizes. Perineural invasion in basal cell carcinoma has been well documented in the literature, but evidence of intravascular invasion has rarely been reported. We describe a rare case of metatypical basal cell carcinoma with intravascular invasion and discuss the clinical management associated with this presentation. The patient was successfully treated with two stages of Mohs micrographic surgery.

Categories: Dermatology, Oncology

Keywords: basal cell carcinoma, metatypical basal cell carcinoma, bcc, basosquamous

\section{Introduction}

Basal cell carcinoma (BCC) is the most common malignancy in humans worldwide [1]. Although it makes up three quarters of all reported skin cancers, BCC rarely metastasizes, with the incidence reported to range from $0.0028 \%$ to $0.5 \%$ [1]. Metastasis is thought to occur via lymphatic and hematogenous spread, most commonly to regional lymph nodes, followed by the lung and bone. While perineural invasion (PNI) in BCC and squamous cell carcinoma (SCC) has been well documented, histologic evidence of intravascular invasion has rarely been reported. Here we present a rare case of metatypical basal cell carcinoma with intravascular invasion located on the lateral shoulder, successfully treated with two stages of Mohs micrographic surgery (MMS).

\section{Case Presentation}

A 76-year-old Caucasian male with a history of SCCs, BCCs, and previously treated metastatic melanoma presented to the dermatology clinic in October 2017 with an erythematous lesion of two-month duration on the left lateral shoulder. He had a history of melanoma in situ of the abdomen excised in 2003, lentigo maligna melanoma of the scalp excised in 2005, and metastatic melanoma of the scalp in 2007, treated with interferon for a year. Physical examination of the left upper extremity revealed a psoriasiform patch $2.1 \mathrm{~cm}$ in diameter on the left lateral shoulder (Figure 1). The lesion was located at a site previously treated for BCC via shave biopsy and destruction six months prior. Due to high suspicion for recurrence of a previously treated BCC, the new lesion was biopsied via shave method. Histologic examination revealed basaloid nests with tumor-stromal clefts and overlying squamoid differentiation of nests beneath an inflamed epidermis (Figure 2), and diagnosis of metatypical basal cell carcinoma was established. MMS was recommended as the treatment of choice due to the tumor's large size $(2.8 \times 2.1 \mathrm{~cm})$, recurrence after prior destruction, and metatypical histology. The patient returned in December, 2017 for MMS, and a tumor-free plane was reached after two 


\section{Cureus}

stages. However, intravascular involvement was noted on stage one of the Mohs sections (Figure 3), and a second stage revealed negative surgical margins. There was no perineural involvement. The patient was then referred to an oncologist for further studies with positron emission tomography (PET) and computed tomography scans, which revealed no metastatic disease. Complete metabolic panel and complete blood count were also within normal limits. Follow-up visit two weeks post-op revealed a clean wound. The patient elected to follow up at the dermatology clinic only. To date, no systemic signs or symptoms were noted.

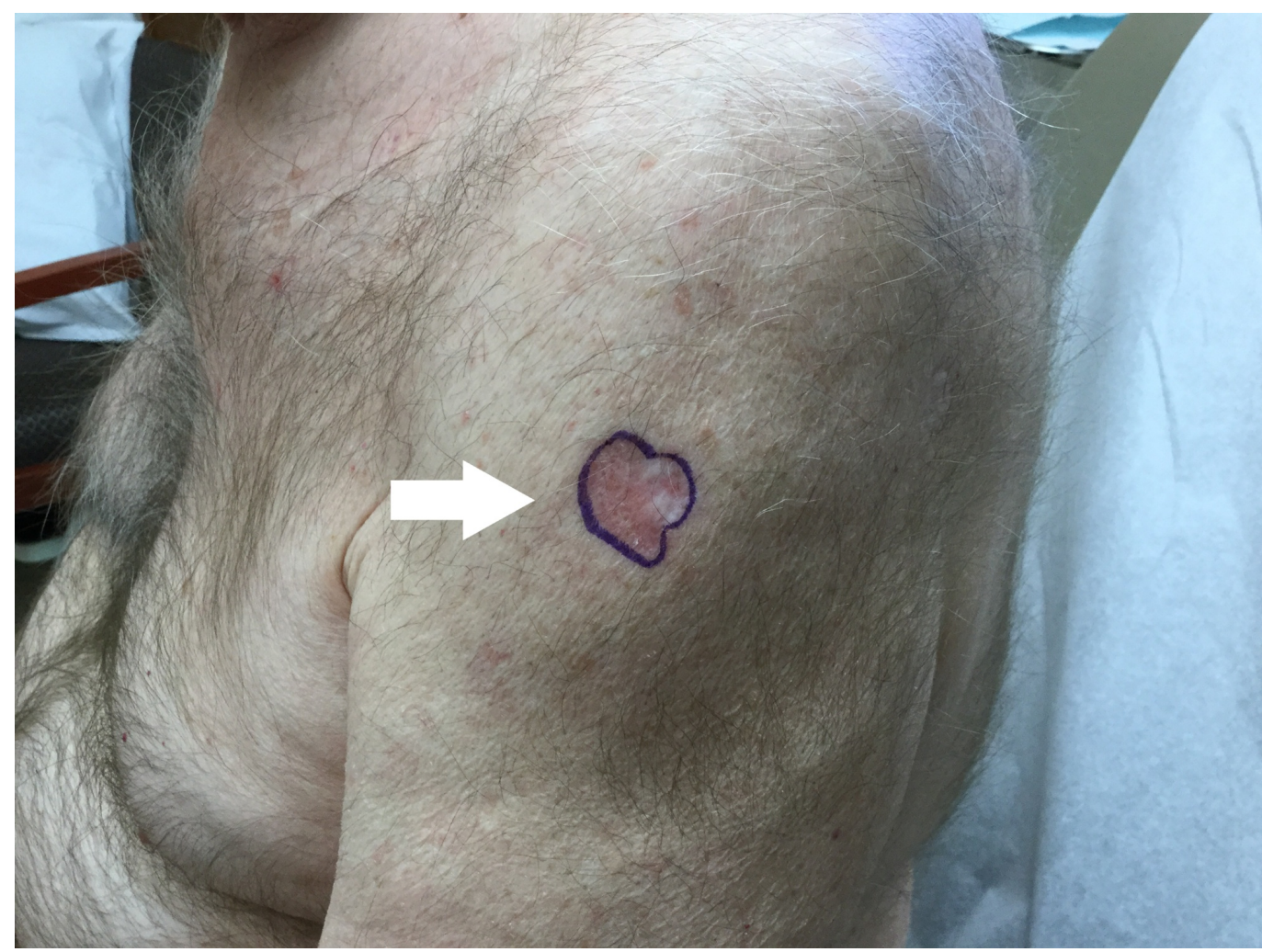

\section{FIGURE 1: Metatypical basal cell carcinoma located on the left} lateral shoulder.

Basal cell carcinoma presenting as a $2.8 \mathrm{~cm}$ psoriasiform patch located on the left lateral shoulder at a site previously treated for basal cell carcinoma. 


\section{Cureus}

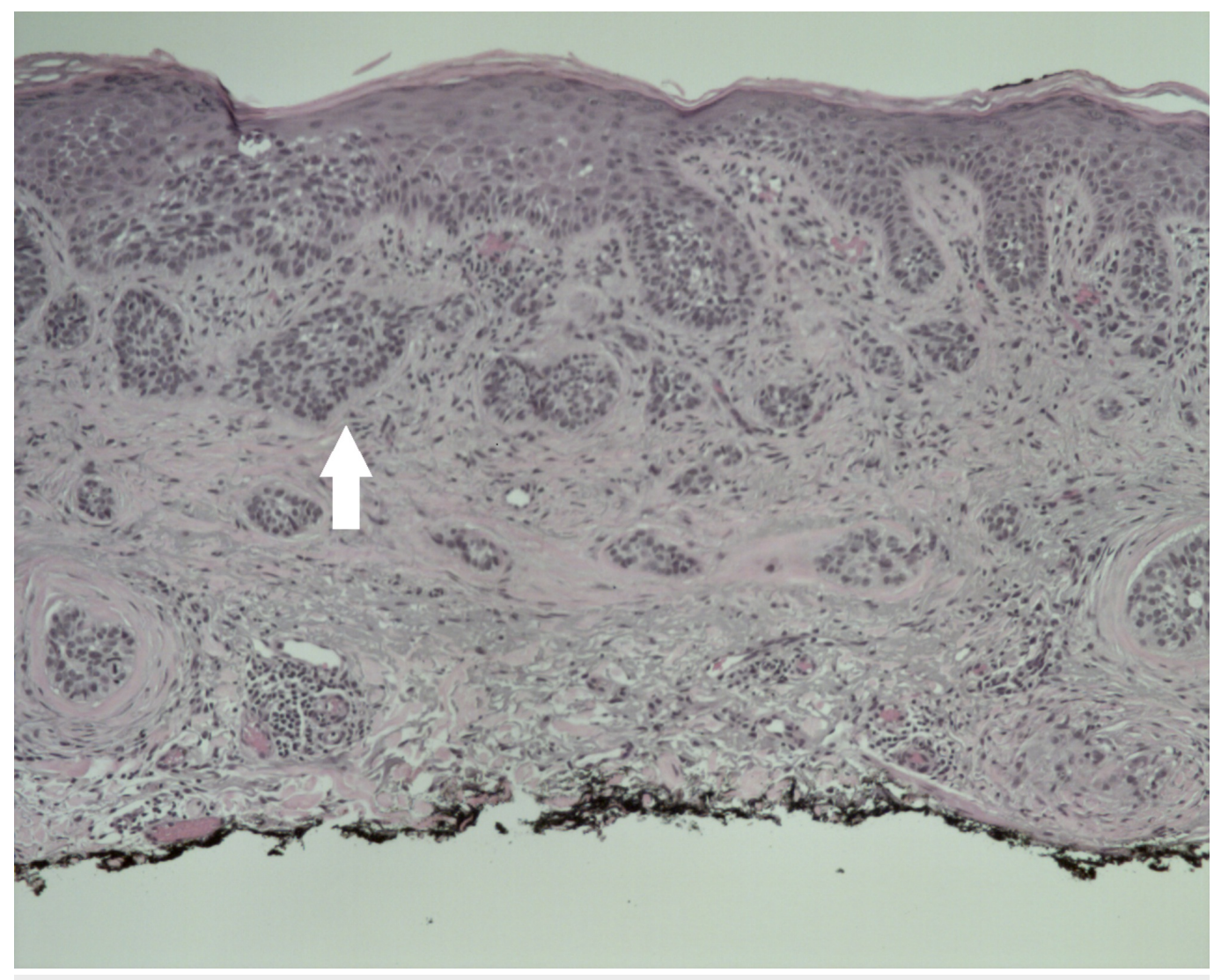

FIGURE 2: Histology of metatypical basal cell carcinoma.

Basaloid nests with tumor-stromal clefts and overlying squamoid differentiation of nests beneath an inflamed epidermis. (hematoxylin-eosin, original magnification $\times 10$ ) 


\section{Cureus}

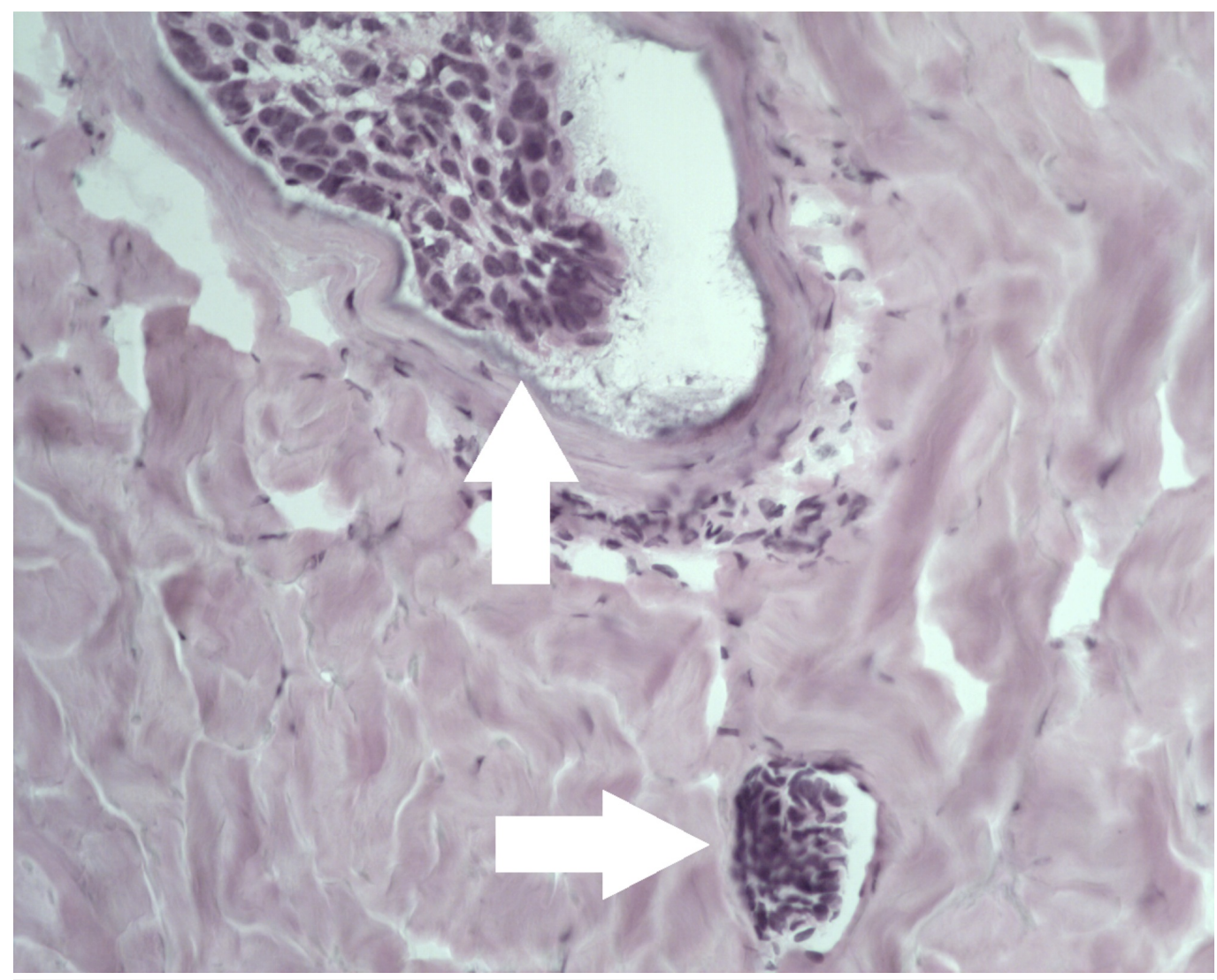

FIGURE 3: Metatypical basal cell carcinoma with intravascular invasion.

Basal cell carcinoma seen in the intralumenal space of a small vessel (top arrow) and another smaller (bottom arrow) on stage 1 of Mohs micrographic surgery. (hematoxylin-eosin, original magnification $\times 20$ )

\section{Discussion}

This is a rare case of metatypical basal cell carcinoma and intravascular involvement. A comprehensive literature search found seven previously reported cases of BCC with intravascular invasion of other subtypes (Table 1) [2-7]. 


\section{Cureus}

\begin{tabular}{|c|c|c|c|c|c|c|}
\hline $\begin{array}{l}\text { Case } \\
\text { No. }\end{array}$ & $\begin{array}{l}\text { Age at } \\
\text { presentation }\end{array}$ & Sex & $\begin{array}{l}\text { Primary } \\
\text { tumor } \\
\text { site }\end{array}$ & $\begin{array}{l}\text { Histological } \\
\text { subtype }\end{array}$ & Treatment & Outcome \\
\hline 1 & 81 & Female & Nasal tip & $\begin{array}{l}\text { Micronodular } \\
\text { and } \\
\text { sclerosing }\end{array}$ & Surgical excision and adjuvant radiation & $\begin{array}{l}\text { No recurrence at } \\
\text { four months }\end{array}$ \\
\hline 2 & 75 & Male & $\begin{array}{l}\text { Left nasal } \\
\text { sidewall }\end{array}$ & $\begin{array}{l}\text { Nodular and } \\
\text { morpheaform }\end{array}$ & MMS (three stages) & $\begin{array}{l}\text { Follow-up not } \\
\text { reported }\end{array}$ \\
\hline 3 & 96 & Female & $\begin{array}{l}\text { Posterior } \\
\text { helix }\end{array}$ & Not reported & MMS (two stages) & $\begin{array}{l}\text { No further } \\
\text { workup }\end{array}$ \\
\hline 4 & 51 & Male & $\begin{array}{l}\text { Upper } \\
\text { chest }\end{array}$ & $\begin{array}{l}\text { Infiltrating } \\
\text { and } \\
\text { micronodular }\end{array}$ & Surgical excision & $\begin{array}{l}\text { Follow-up not } \\
\text { reported }\end{array}$ \\
\hline 5 & 51 & Male & $\begin{array}{l}\text { Right } \\
\text { posterior } \\
\text { upper } \\
\text { shoulder }\end{array}$ & Infiltrating & $\begin{array}{l}\text { MMS after two recurrences were } \\
\text { treated with electrodesiccation and } \\
\text { curettage and surgical excision, } \\
\text { respectively }\end{array}$ & $\begin{array}{l}\text { Death from } \\
\text { pulmonary } \\
\text { metastasis } 13 \\
\text { years later }\end{array}$ \\
\hline 6 & $71-72$ & Male & Left chin & Not reported & Not specified & $\begin{array}{l}\text { No recurrence at } \\
\text { nine years }\end{array}$ \\
\hline 7 & 27 & Male & Left cheek & Infiltrating & Surgical excision & $\begin{array}{l}\text { Death from } \\
\text { pulmonary } \\
\text { metastasis four } \\
\text { years later }\end{array}$ \\
\hline
\end{tabular}

\section{TABLE 1: A summary of cases found in the literature of basal cell carcinoma with intravascular involvement.}

The cases are arranged numerically in order of publication date, starting from the most recent. Patient 1 through 5 had intravascular involvement of the primary tumor. Patients 6 and 7 had intravascular involvement of a recurring tumor. Patients 5,6 , and 7 had multiple recurrences and subsequent metastases.

MMS: Mohs micrographic surgery

Since metastatic BCC is associated with a five-year survival rate of only $10 \%$, it is important to determine whether BCC with intravascular involvement is associated with an increased risk of metastasis and thus warrants more aggressive workup and treatment [8]. More aggressive histologic subtypes of BCC, including morpheaform, micronodular, and metatypical, are more likely to metastasize. Other risk factors for a metastatic event include the male sex, tumor of the head and neck, large tumor size $(>2 \mathrm{~cm})$, recurrence at the primary site, immunosuppression, and PNI. PNI in non-melanoma skin cancers is associated with a much higher risk of local recurrence and metastasis, despite a much higher risk in SCC than in BCC [9]. While there exist National Comprehensive Cancer Network guidelines for management of non-melanoma skin cancers with PNI, the clinical relevance and therapeutic implication of intravascular invasion in BCC is not well understood due to its rarity. Intravascular 
involvement was thought to be associated with an increased risk of hematogenous spread and consequent metastasis, however, there is a paucity of literature to support.

PET scan and sentinel node biopsy (SLNB)are often used to detect metastatic disease in various cancers. Although their utility for BCC is not well documented due to low incidence of metastasis, PET scan and SLNB have been successful in detecting metastatic BCC according to some reports [10-11]. Therefore, PET scan and/or SLNB are reasonable measures to undertake in a patient with BCC when multiple risk factors for metastasis are present. Our patient had numerous risk factors, including large tumor size, recurrence, the male sex, and metatypical subtype. Our case, along with the rare previous reports, raises the important question of the potential clinical significance of finding intravascular BCC and the extent of workup indicated as well as the likely prognosis. In this case, with negative PET scan findings and no clinically palpable lymph nodes, the patient and his oncologist elected not to have a sentinel node biopsy performed. However, frequent close follow-up at the dermatology clinic is warranted due to his previous history of metastatic melanoma as well as the poorly understood prognosis of BCC with intravascular invasion.

\section{Conclusions}

We describe a rare case of metatypical basal cell carcinoma with intravascular invasion and discuss the clinical management associated with this presentation. The patient was successfully treated with two stages of Mohs micrographic surgery. While the clinical significance of intravascular invasion remains unknown, our patient had multiple risk factors for metastasis, including large tumor size, recurrence, the male sex, and metatypical subtype, but PET scan findings were negative. However, frequent close follow-up at the dermatology clinic is warranted due to his previous history of metastatic melanoma, multiple risk factors for metastasis, as well as the poorly understood prognosis of BCC with intravascular invasion.

\section{Additional Information}

\section{Disclosures}

Human subjects: Consent was obtained by all participants in this study. Conflicts of interest: In compliance with the ICMJE uniform disclosure form, all authors declare the following:

Payment/services info: All authors have declared that no financial support was received from any organization for the submitted work. Financial relationships: All authors have declared that they have no financial relationships at present or within the previous three years with any organizations that might have an interest in the submitted work. Other relationships: All authors have declared that there are no other relationships or activities that could appear to have influenced the submitted work.

\section{References}

1. Wong CSM, Strange RC, Lear JT: Basal cell carcinoma. BMJ. 2003, 327:794-798.

2. Lonie S, Niumsawatt V, Castley A: A prognostic dilemma of basal cell carcinoma with intravascular invasion. Plast Reconstr Surg Glob Open. 2016, 4:1046. 10.1097/gox.0000000000001046

3. Milam E, Bogart M, Manolson P: Basal cell carcinoma with intravascular invasion: a therapeutic conundrum. Dermatol Surg. 2016, 42:776-779. 10.1097/dss.0000000000000712

4. Shea K, Weinberger CH, Cook D: Intravascular basal cell carcinoma. Dermatol Surg. 2016, 42:123-124. 10.1097/dss.0000000000000563

5. Machan M, Kroh JM, Hunt E, Fraga G: Basal cell carcinoma with vascular invasion. Dermatol Online. 2012, 18:13.

6. Robinson JK, Dahiya M: Basal cell carcinoma with pulmonary and lymph node metastasis causing death. Arch Dermatol. 2003, 139:643-648. 10.1001/archderm.139.5.643 


\section{Cureus}

7. Domarus Hv, Stevens PJ: Metastatic basal cell carcinoma. J Am Acad Dermatol. 1984, 10:10431060. 10.1016/S0190-9622(84)80334-5

8. Spates T, Mellette JR, Fitzpatrick J: Metastatic basal cell carcinoma. Dermatol Surg. 2003, 29:650-652. 10.1046/j.1524-4725.2003.29156.x

9. Gupta A, Veness M, De'Ambrosis B, Selva D, Huilgol SC: Management of squamous cell and basal cell carcinomas of the head and neck with perineural invasion. Australas J Dermatol. 2016, 57:3-13. 10.1111/ajd.12314

10. Grekin SJ, Bichakjian CK, Sabel MS, Chepeha DB, Fullen DR: Metastatic basal cell carcinoma from a small tumor with lymphatic invasion. J Am Acad Dermatol. 2011, 65:16-17. 10.1016/j.jaad.2010.12.009

11. Yoshida Y, Shiomi T, Tahira M, Yamamoto O: Metastatic basosquamous carcinoma detected by sentinel lymph node biopsy. J Dermatol. 2013, 40:635-637. 10.1111/1346-8138.12204 